\title{
Recombinant human granulocyte-macrophage colony-stimulating factor: effect of glycosylation on pharmacokinetic parameters
}

\author{
Guillermo Marini \\ Laboratorio de Cultivos Celulares \\ Facultad de Bioquímica y Ciencias Biológicas \\ Universidad Nacional del Litoral \\ Ciudad Universitaria \\ Paraje "El Pozo", S3000ZAA \\ Santa Fe, Argentina \\ Tel/Fax: 5403424552928 \\ E-mail: guillemarini@yahoo.com.ar
}

\section{Guillermina Forno}

Laboratorio de Cultivos Celulares

Facultad de Bioquímica y Ciencias Biológicas

Universidad Nacional del Litoral Ciudad Universitaria

Paraje "El Pozo", S3000ZAA

Santa Fe, Argentina

Tel/Fax: 5403424552928

E-mail: gforno@fbcb.unl.edu.ar

\section{Ricardo Kratje}

Laboratorio de Cultivos Celulares Facultad de Bioquímica y Ciencias Biológicas

Universidad Nacional del Litoral

Ciudad Universitaria

Paraje "El Pozo", S3000ZAA

Santa Fe, Argentina

Tel/Fax: 5403424552928

E-mail: rkratje@fbcb.unl.edu.ar

\section{Marina Etcheverrigaray*}

Laboratorio de Cultivos Celulares

Facultad de Bioquímica y Ciencias Biológicas

Universidad Nacional del Litoral

Ciudad Universitaria

Paraje "El Pozo", S3000ZAA

Santa Fe, Argentina

Tel/Fax: 543424564397

E-mail: marina@fbcb.unl.edu.ar

Keywords: glycosylation, pharmacokinetic parameters, rhGM-CSF.

Abbreviations: BSA: bovine serum albumin

CHO: Chinese hamster ovary

CL: total plasma clearance

$\mathrm{C}_{\max }$ : maximum plasma concentration

ELISA: enzyme-linked immunosorbent assay

FCS: fetal calf serum

ip: intraperitoneal

iv: intravenous

PBS: phosphate-buffered saline

rhGM-CSF: recombinant human granulocyte-macrophage colony-stimulating factor

$\mathrm{t}_{1 / 2} \alpha$ : distribution half-life

$\mathrm{t}_{1 / 2}: \beta$ terminal half-life

TBS: Tris-buffered saline

$t_{\max }$ : time to reach the maximum plasma concentration

\footnotetext{
*Corresponding author
} 
The pharmacokinetic behaviour of the non-glycosylated, bacterially-derived recombinant human granulocytemacrophage colony-stimulating factor (rhGM-CSF) and the glycosylated mammalian product was studied after intra and extra vascular administration of a single dose in rodents. Each route of administration gave a different rhGM-CSF concentration-time profile. After extra vascular administration of equivalent doses, a higher peak concentration and faster elimination were observed in the group treated with the $E$. coli-derived cytokine. The faster elimination resulted in a return to pre-treatment plasma levels after $12 \mathrm{hrs}$, versus $48 \mathrm{hrs}$ following the administration of glycosylated rhGMCSF. After intravascular administration, clearance of rhGM-CSF was significantly decreased by the presence of carbohydrates. Non-significant differences in the terminal phase of the biphasic kinetics were found, but the distribution phase was significantly longer for the glycosylated form.

Colony-stimulating factors are a family of glycoproteins that modulate the haematopoietic process and control survival, proliferation, differentiation, and functional ability of mature haematopoietic progenitors, with frequent overlapping activities (Armitage, 1998). The human granulocyte-macrophage colony-stimulating factor (hGMCSF) belongs to this family. It is produced by a variety of cells including lymphocytes, endothelial cells, fibroblasts, monocytes, as well as some malignant cells (Fleetwood et al. 2005). Human GM-CSF cDNA codes for a protein with 144 amino acids, with a leading peptide of 17 amino acids, two N-linked glycosylation sites, four potential O-linked glycosylation sites, and two disulfide bridges (Kaushansky et al. 1987). Due to the glycosylation, the apparent molecular mass of the protein varies from 18 to $32 \mathrm{kDa}$. It is classified as a multilineage colony-stimulating factor because it stimulates the proliferation and differentiation of haematopoietic progenitor cells of neutrophil, eosinophil, and monocyte origin. Recombinant human granulocytemacrophage colony-stimulating factor (rhGM-CSF) is approved by the US Food and Drug Administration (FDA) for the acceleration of myeloid recovery following autologous bone marrow transplantation and in patients who fail to engraft after bone marrow transplantation. Evidence also supports the use of GM-CSF in many other clinical settings in which patients are neutropenic (Trindade et al. 1998; Bilgin et al. 2001).

Three synthetic human GM-CSFs have been produced by using recombinant DNA technology, employing different expression systems: bacteria, yeast, and mammalian cells (Hussein et al. 1995). The selection of the host cell to produce the recombinant protein is important because these preparations are not identical and present different characteristics, such as the amino acid sequence, the size of the protein, and the degree of glycosylation. In the case of rhGM-CSF, the degree of glycosylation can influence pharmacokinetics, biologic activity, antigenicity, and toxicity (Wadhwa et al. 1996; Armitage, 1998; Wadhwa et al. 1999). Although the product from mammalian cells is more similar to the natural protein, only commercial preparations produced in E. coli or S. cerevisiae are presently available for clinical application.

The main objective of the current study was to analyze the influence of the glycosylation of rhGM-CSF on kinetic parameters such as clearance, distribution, elimination halflife, and maximum plasma concentration, employing rats and mice as model systems. Therefore, both glycosylated rhGM-CSF produced in Chinese hamster ovary (CHO) cells in our laboratory and non-glycosylated rhGM-CSF produced in a bacterial system (Growgen, Bioprofarma S.A., Argentina) were employed in order to compare their pharmacokinetics.

\section{MATERIALS AND METHODS}

\section{Cell Culture}

To obtain glycosylated rhGM-CSF, a recombinant CHO.K1 cell line adapted to grow in suspension was used (Bollati Fogolín et al. 2004). These cells were inoculated at a concentration of $1 \times 10^{5}$ cells $/ \mathrm{mL}$ in spinner flasks (Techne, UK) with a $1.2 \mathrm{~L}$ working volume stirred at $50 \mathrm{rpm}$. The culture medium was a 1:1 (v/v) mixture of DMEM and Ham's F12 (both from Gibco BRL, USA) supplemented with sodium hydrogencarbonate $2.44 \mathrm{~g} / \mathrm{L}$ (Gibco), anhydrous glucose $1.08 \mathrm{~g} / \mathrm{L}$ (Sigma, USA), sodium pyruvate $110 \mathrm{mg} / \mathrm{L}$ (Gibco), aspartic acid $39 \mathrm{mg} / \mathrm{L}$ (Sigma), gentamicin sulphate $50 \mu \mathrm{g} / \mathrm{mL}$ (Gibco), Pluronic F-68 50

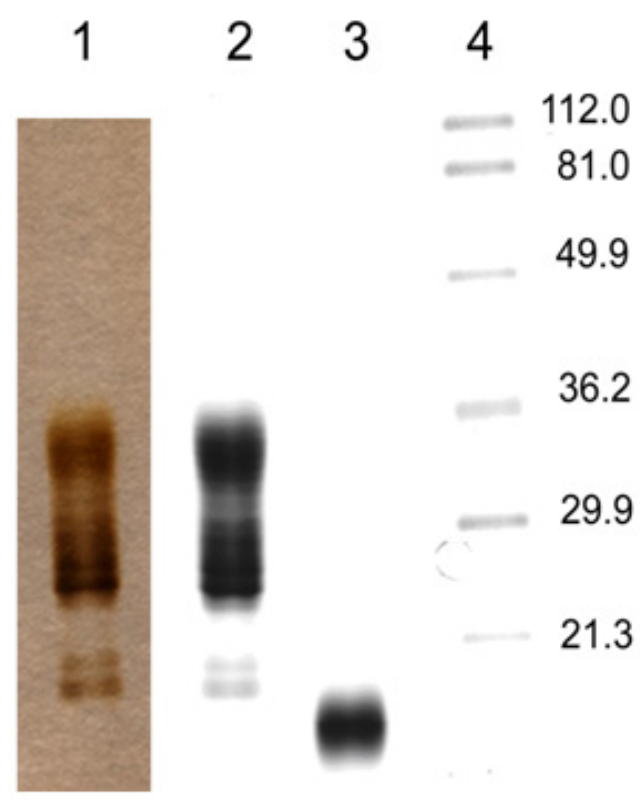

Figure 1. SDS-PAGE analysis of rhGM-CSF followed by silver staining (lane 1) or Western blot (lanes 2 and 3). Lane 1: purified CHO-derived rhGM-CSF. Lane 2: $\mathrm{CHO}-$ derived rhGM-CSF from culture supernatant. Lane 3: $E$. coliderived rhGM-CSF. Lane 4: Molecular weight standards (kDa). 
rhGM-CSF: effect of glycosylation on pharmacokinetic parameters

Table 1. Pharmacokinetics of non-glycosylated and glycosylated rhGM-CSF in mice after a single ip injection.

\begin{tabular}{|c|c|c|c|c|c|}
\hline & $\begin{array}{c}\boldsymbol{C}_{\max } \\
(\mathbf{n m o l} / \mathbf{m L})\end{array}$ & $\begin{array}{c}\boldsymbol{t}_{\max } \\
(\mathbf{m i n})\end{array}$ & $\begin{array}{c}\boldsymbol{t}_{\mathbf{1 / 2}} \boldsymbol{\alpha} \\
(\mathbf{m i n})\end{array}$ & $\begin{array}{c}\boldsymbol{t}_{1 / 2} \boldsymbol{\beta} \\
(\mathbf{m i n})\end{array}$ & $\begin{array}{c}\mathrm{CL} \\
(\mathbf{m L} / \mathbf{m i n})\end{array}$ \\
\hline non-glycosylated rhGM-CSF & $0.018 \pm 0.001$ & 20 & $10 \pm 2$ & $260 \pm 80$ & $0.26 \pm 0.07$ \\
\hline glycosylated rhGM-CSF & $0.0028 \pm 0.0005$ & 30 & $60 \pm 10$ & $1,500 \pm 200$ & $0.09 \pm 0.02$ \\
\hline
\end{tabular}

$\mu \mathrm{g} / \mathrm{mL}$ (Gibco), and fetal calf serum (FCS) $0.2 \%(\mathrm{v} / \mathrm{v})$ (Bioser, Argentina). The $\mathrm{pH}$ was adjusted to 7.4. When a cell density of $8 \times 10^{5}$ cells $/ \mathrm{mL}$ was reached, daily changes of medium were carried out during the 9-day culture. The cell suspension $(600 \mathrm{~mL})$ was centrifuged at $1,000 \mathrm{rpm}$ for $10 \mathrm{~min}$, the medium removed, replaced with fresh medium, and the cells returned to the spinner flask. The culture was incubated at $37^{\circ} \mathrm{C}$ in an atmosphere of $95 \%$ air supplemented with $5 \% \mathrm{CO}_{2}(\mathrm{v} / \mathrm{v})$ at $99 \%$ humidity.

Glucose and lactate were determined routinely with an YSI Model 2000 glucose/lactate analyzer (Yellow Springs Instruments, Yellow Springs, USA). The ammonium concentration was determined using a kit based on the Berthelot reaction (Sociedad de Bioquímicos, Santa Fe, Argentina). The viable cell number and total cell number were determined by the Trypan Blue exclusion method. A competitive GM-CSF enzyme-linked immunosorbent assay (ELISA) was used for the quantification of rhGM-CSF (Bollati Fogolín et al. 2002). Briefly, the technique involved coating 96 well microtiter plates with $16.5 \mathrm{ng}$ nonglycosylated rhGM-CSF (Growgen). It was also used as a competitor in solution, serially diluted from 200 to 0.195 $\mathrm{ng} / \mathrm{mL}$ in phosphate-buffered saline (PBS) $\left(\mathrm{KH}_{2} \mathrm{PO}_{4} 0.6\right.$ $\mathrm{g} / \mathrm{L}, \mathrm{Na}_{2} \mathrm{HPO}_{4} \quad 0.78 \mathrm{~g} / \mathrm{L}$ and $\mathrm{NaCl} 8.8 \mathrm{~g} / \mathrm{L}(\mathrm{pH} 7.4)$ ), supplemented with $5 \%(\mathrm{v} / \mathrm{v})$ FCS. Samples were assayed in serial 1:2 dilutions. Competition was carried out by incubating the coated plates with $100 \mu \mathrm{L}$ of competitor or samples with $100 \mu \mathrm{L}$ M7E10 ascites 1:100,000 in PBS-5\% (v/v) $\mathrm{FCS}$, at $37^{\circ} \mathrm{C}$ for $2 \mathrm{hrs}$. After washing, $100 \mu \mathrm{L}$ of rabbit anti-mouse immunoglobulins-HRP (DAKO, USA) conjugate 1:1,000 was added to the wells. After incubation for $1 \mathrm{hr}$ at $37^{\circ} \mathrm{C}$, plates were washed and $100 \mu \mathrm{L}$ substrate was added. Optical densities were measured at $450 \mathrm{~nm}$ with an ELISA reader (Labsystem Multyskan MCC/340, Finland).

\section{Purification of rhGM-CSF}

The glycoprotein that was present in the micro filtrated cell culture supernatants was purified by immunoaffinity chromatography using the M7E10 anti-GM-CSF monoclonal antibody (Forno et al. 2004). Elution was performed using $0.5 \mathrm{M}$ acetic acid, $0.15 \mathrm{M} \mathrm{NaCl}$ ( $\mathrm{pH} 3.0$ ). This fraction was neutralized with $1 \mathrm{M}$ Tris/ $\mathrm{HCl}(\mathrm{pH} 9.0)$. Using ultrafiltration, the purified rhGM-CSF was concentrated and buffer-exchanged into PBS. Purity was evaluated using discontinuous SDS-PAGE by means of $15 \%$ polyacrylamide resolving gels and 3\% stacking gels. Separated proteins were stained using silver or transferred onto a $0.45 \mu \mathrm{m}$ nitrocellulose membrane (Bio-Rad, USA). After blocking for $1 \mathrm{hr}$ at room temperature with Trisbuffered saline (TBS) containing $1 \%(\mathrm{w} / \mathrm{v})$ bovine serum albumin (BSA), blots were incubated with mAb $\mathrm{CC} 1 \mathrm{H} 7$ diluted 1:1,000 in TBS containing $0.1 \%(w / v)$ BSA. After washing thrice with TBS, peroxidase-labelled rabbit anti-mouse immunoglobulins (DAKO) were added at a dilution of $1: 2,000$ in TBS- $0.1 \%(\mathrm{w} / \mathrm{v})$ BSA for $1 \mathrm{hr}$ at room temperature. The analysis of cytokine-bound antibody was carried out using a chemiluminiscence detection system (GE Healthcare, USA) and membranes were exposed to light-sensitive films (Kodak, USA) for different times.

\section{Determination of pharmacokinetics parameters of rhGM-CSF}

Intraperitoneal administration. Two groups (64 mice per group) of two-month-old male and female BALB/c mice (Comisión Nacional de Energía Atómica, Argentina) were injected intraperitonealy (ip) with $0.41 \mathrm{nmol}$ of glycosylated or non-glycosylated protein in a total volume of $200 \mu \mathrm{L}$, respectively. Mice were housed in a temperature-controlled room at $23^{\circ} \mathrm{C}$, with a $12 \mathrm{hrs}$ light period and free access to food and water. Blood samples were taken at 10, 15, 20, $30 \mathrm{~min}$ and 1, 2, 3, 4, 5, 6, 7, 12, 24, and 48 hrs post-dose via retroorbital puncture. At each time point, blood was collected from four mice in eppendorf tubes with $20 \mu \mathrm{L}$ of $0.5 \%$ heparin in PBS. Blood samples from non-injected mice were also collected.

Intravenous administration. Two groups (8 rats per group) of two-month-old male and female Wistar rats (Comisión Nacional de Energía Atómica, Argentina) were injected intravenously (iv) into the tail vein with $3.4 \mathrm{nmol}$ of glycosylated or non-glycosylated protein in a total volume of $250 \mu \mathrm{L}$. Animals were housed in a temperaturecontrolled room at $23^{\circ} \mathrm{C}$, with a $12 \mathrm{hrs}$ light period and free access to food and water. Blood samples were taken at 2.5, $5,7.5,10,15,20,30 \mathrm{~min}$ and $1,2,3,4$, and 24 hrs postdose via retroorbital puncture. At each time point, blood was collected from four rats in eppendorf tubes with $20 \mu \mathrm{L}$ of $0.5 \%$ heparin in PBS. Blood samples from non-injected rats were also collected. 




Figure 2. Pharmacokinetic profile of non-glycosylated and glycosylated rhGM-CSF following ip administration of a single dose of $0.41 \mathrm{nmol}$ of rhGM-CSF in mice. Blood was collected at the time points indicated and assayed for levels of rhGM-CSF by ELISA. Inset shows the data between 0 and $120 \mathrm{~min}$

All animal experimental protocols were in accordance with the "Principles of Laboratory Animal Care" (NIH publication 85-23, and all subsequent revisions thereof).

Quantification of rhGM-CSF in plasma. Blood samples were centrifuged at 2,000 rpm for $10 \mathrm{~min}$ at $20^{\circ} \mathrm{C}$ using an Eppendorf 5403 centrifuge (Germany), and the plasma obtained was stored at $-20^{\circ} \mathrm{C}$ until determination of rhGMCSF concentration by ELISA. The competitive GM-CSF ELISA previously described was used for the quantification of rhGM-CSF (Bollati Fogolín et al. 2002).

Determination of pharmacokinetic parameters. Plots of rhGM-CSF concentration versus time were constructed, and pharmacokinetic parameters were calculated from these plots (Shargel et al. 2005). Maximum plasma concentration $\left(C_{\max }\right)$, the time to reach the $C_{\max }\left(t_{\max }\right)$, constants of the initial phase ( $A$ and $\alpha)$ constants of the elimination phase $(B$ and $\beta)$, distribution/post-absorption half-life $\left(\begin{array}{ll}t_{1 / 2} & \alpha\end{array}\right)$, terminal half-life $\left(t_{1 / 2} \beta\right)$, and total plasma clearance (CL) were calculated with Microcal Origin software version 5.0 (Microcal Software, USA). Differences between the two preparations were evaluated by a paired Student's test. Probabilities lower than 0.05 were considered significant.

\section{RESULTS}

Glycosylation, the addition of sugar residues to a peptide backbone, is a significant post-translational modification in eukaryotic cells and plays important roles in defining the properties of glycoproteins, including biological activity, immunogenicity, pharmacokinetics, solubility, and protease resistance (Rudd et al. 2001; Mitra et al. 2006). Since it is important to understand the influence of glycosylation on the pharmacokinetic behaviour of rhGM-CSF, we have studied glycosylated and non-glycosylated rhGM-CSF to gain insight into how the native glycosylated human protein might behave.

\section{Production and purification of glycosylated rhGM- CSF}

GM-CSF was produced by recombinant CHO.K1 cells adapted to grow in suspension using spinner flasks as described in Materials and Methods. The maximum viable cell density was $2.6 \times 10^{6}$ cells $/ \mathrm{mL}$ which was reached after 6 days, and the GM-CSF concentration was in the range $1,000-3,000 \mathrm{ng} / \mathrm{mL}$. The ammonium concentration in the medium was below $2.5 \mathrm{mM}$ during the entire process; the 


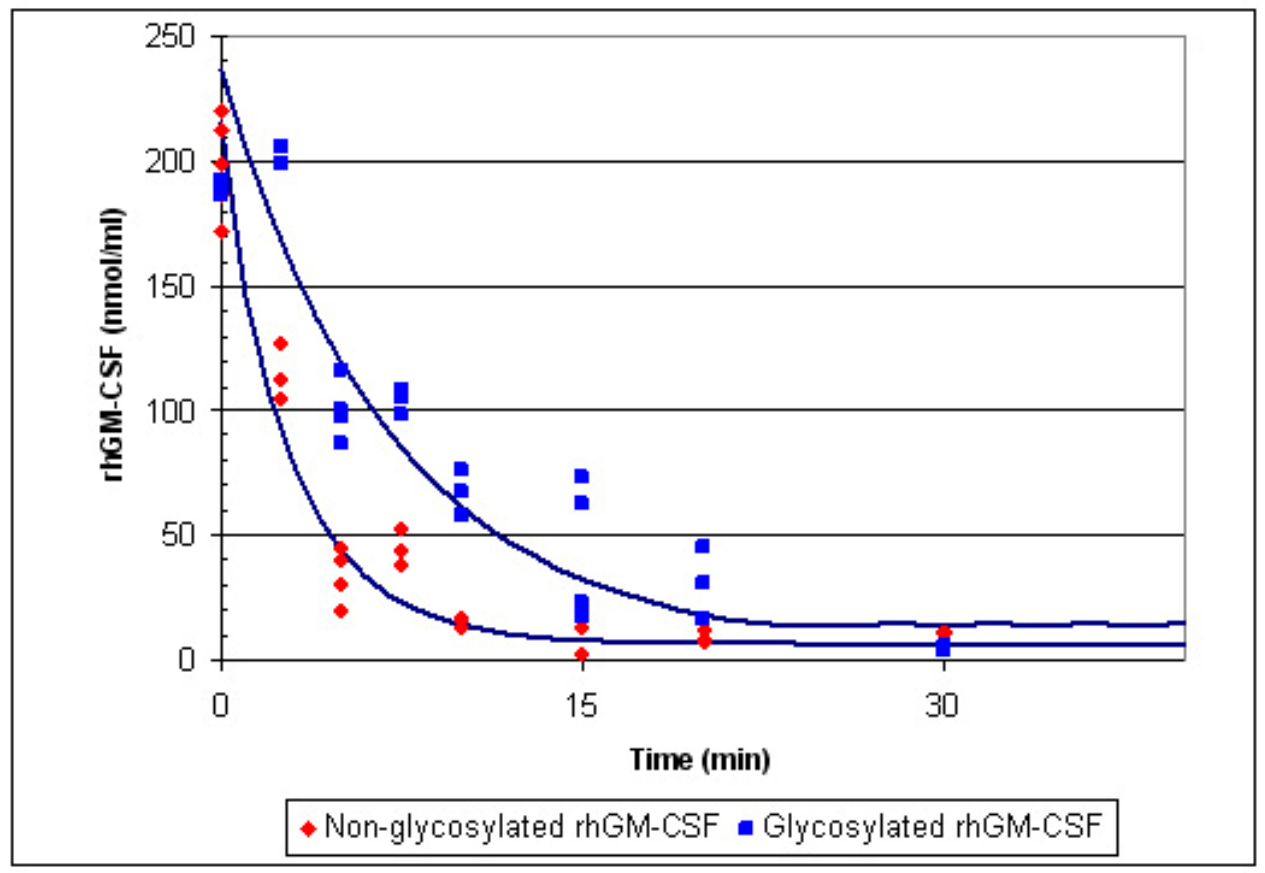

Figure 3. Pharmacokinetic profiles of non-glycosylated and glycosylated rhGM-CSF in rats following a single iv administration of $3.4 \mathrm{nmol}$ rhGM-CSF. Blood was collected at the time points indicated and assayed for levels of rhGM-CSF by ELISA. Individual data points and the fitting using non-compartmental analysis of the data are represented.

maximum lactate concentration was $14 \mathrm{mM}$, and a minimum glucose concentration of $44 \mu \mathrm{M}$ was reached on day 9.

The purification of the secreted rhGM-CSF was achieved by immunoaffinity chromatography employing a monoclonal antibody (M7E10). Preparations were judged to be more than $95 \%$ pure, based on densitometry of SDSPAGE protein bands. They exhibited significant molecular weight microheterogeneity with multiple closely-spaced bands of apparent molecular masses between 18-32 $\mathrm{kDa}$ (Figure 1), in agreement with previous results from our laboratory (Forno et al. 2004).

\section{Determination of plasma pharmacokinetics of glycosylated and non-glycosylated rhGM-CSF}

The pharmacokinetic profiles of glycosylated and nonglycosylated rhGM-CSF were determined following ip or iv administration of a single dose of protein as described below.

Intraperitoneal administration. Figure 2 shows the mean plasma concentration of rhGM-CSF following ip administration in mice. There was no apparent difference in the rhGM-CSF level between males and females (data not shown). The maximal level was 6.4-fold higher for nonglycosylated rhGM-CSF and it was reached $20 \mathrm{~min}$ postinjection, whereas the concentration of glycosylated rhGMCSF continued rising until 30 min after injection. The $C_{\max }$ values were $0.018 \pm 0.001 \mathrm{nmol} / \mathrm{mL}$ and $0.0028 \pm 0.0005$ $\mathrm{ng} / \mathrm{mL}$ for non-glycosylated and glycosylated rhGM-CSF, respectively.

After the drug absorption phase, the elimination pattern for each protein was characterized by an initial post-absorption phase followed by an elimination phase as it is described by Shargel et al. (2005), and analyzed in terms of its circulating half-life. The glycosylated form exhibited a significantly longer $t_{1 / 2}$ value than the non-glycosylated protein for both post-absorption and elimination phases. Thus, the glycosylated rhGM-CSF showed a postabsorption phase $\left(\mathrm{t}_{1 / 2} \alpha\right)$ of $60 \mathrm{~min}$, followed by a half-life of elimination phase $\left(\mathrm{t}_{1 / 2} \beta\right)$ of $1,500 \mathrm{~min}$. This slow decline in the level of the glycosylated protein in blood was consistent with its low clearance value $(0.09 \mathrm{~mL} / \mathrm{min})$. For the non-glycosylated protein, $t_{1 / 2} \alpha$ and $t_{1 / 2} \beta$ values were around 6 times lower than those for the glycosylated rhGMCSF (Table 1), reflecting a faster clearance for the E. coliderived $\mathrm{rhGM}-\mathrm{CSF}(0.26 \mathrm{~mL} / \mathrm{min})$.

Intravenous administration. Figure 3 shows the plasma concentration of rhGM-CSF following iv administration in rats. There was no apparent difference in the rhGM-CSF level between males and females (data not shown). The mean plasma concentration of rhGM-CSF declined biexponentially after injection, and the concentration of the non-glycosylated and glycosylated rhGM-CSF were similar to basal values at 15 and $30 \mathrm{~min}$ post-dose, respectively. Curve fitting and calculation of the $A, B, \alpha$, and $\beta$ values 
allowed us to determine half-lives for both clearance phases in the case of each form of rhGM-CSF, as shown in Table 2.

For $t_{1 / 2} \beta$, no significant differences were detected between the non-glycosylated and glycosylated forms of rhGMCSF. In contrast, the non-glycosylated form of rhGM-CSF demonstrated an increased rate of initial distribution, as indicated by its significantly reduced $t_{1 / 2} \alpha$. This value is consistent with a faster clearance for the $E$. coli-derived rhGM-CSF $(2.83 \mathrm{~mL} / \mathrm{min})$ as compared to $1.07 \mathrm{~mL} / \mathrm{min}$ for the glycosylated protein.

\section{DISCUSSION}

It is often difficult to accurately forecast the pharmacokinetic behaviour of native proteins, even when their structural properties are well characterized. In the case of glycosylated proteins, it is known that this modification frequently affects glomerular filtration, stability, immunogenicity, tissue localization, cell uptake, liver excretion, etc. As a heavily glycosylated member of the haematopoietic cytokine family, reports support the key role of the carbohydrate chains of hGM-CSF in terms of toxicity (Denzlinger el al. 1993; Dorr, 1993) and immunogenicity (Gribben et al. 1990; Revoltella et al. 1997).

This study explores the clearance of two rhGM-CSF preparations produced by different host cells. We used a mammalian cell expression system to produce glycosylated rhGM-CSF that structurally resembles the natural molecule (Cebon et al. 1990). The glycosylated rhGM-CSF was produced from a recombinant CHO.K1 cell line that was grown in suspension culture. A single immunoaffinity isolation procedure was applied, resulting in a purity of $\geq 95 \%$. Following purification, the CHO cell-expressed rhGM-CSF was compared to a commercially-available, bacterially-expressed, non-glycosylated version.

When ip administration was studied in mice, we found that the non-glycosylated protein had a more rapid absorption, with an earlier and higher $C_{\max }$ than the glycosylated protein.

After maximum levels for both rhGM-CSF molecules were reached, a two compartment pharmacokinetic model was followed. Half-lives $\alpha$ and $\beta$ were longer for the glycosylated protein, in accordance with a decrease in the clearance rate. This pharmacokinetic profile of glycosylated rhGM-CSF resulted in a relatively stable plasma concentration, which could be therapeutically more effective than the high peaks and troughs following injections of a molecule with a relatively short half-life such as the non-glycosylated cytokine. Similar behaviour was found following single subcutaneous administration of yeast-derived rhGM-CSF in patients (Stute et al. 1995).

Following iv administration, we showed that the clearance of the rhGM-CSF was significantly decreased by the addition of carbohydrates. We did not find a significant difference in the terminal phase of the biphasic pharmacokinetics but, in contrast, the $t_{1 / 2} \alpha$ value was significantly higher for the glycosylated form.

$\mathrm{N}$-linked and O-linked glycosylation are common modifications of plasma proteins. Although in many instances enzymatic deglycosylation or generation of a nonglycosylated recombinant form results in the maintenance of its in vitro activity, the in vivo behaviour of the protein can be significantly altered. rhGM-CSF exemplifies this general finding, in which a non-glycosylated recombinant protein increases its rate of clearance in mice and rats. The same effect was observed for other glycoproteins used as therapeutics (Chitlaru et al. 2002; Koury, 2003).

Several mechanisms that account for this in vivo behaviour have been suggested. An increase in molecular size can reduce clearance via glomerular filtration. In the case of the glycosylated rhGM-CSF the more acidic glycoforms exhibit a molecular weight of $35,000 \mathrm{Da}$ based on migration on SDS-PAGE larger than that observed for the non-glycosylated form $(14,000 \mathrm{Da})$. This property has been employed to design new therapeutics with improved efficacy. PEGylation increases the plasma half-life of a protein by decreasing the rate of systemic clearance, which reduces the frequency of dosing. Moreover, several PEGylated interferons have gained regulatory approval since 2000 (Walsh, 2003).

Another major factor responsible for the extended elimination half-life of glycoproteins is the presence of sialic acids on the glycans, which inhibit binding to hepatic asialoglycoprotein clearance receptors that have specificity for terminal galactose or $\mathrm{N}$-acetylgalactosamine residues, and which vary markedly among mammals (Park and

Table 2. Pharmacokinetics of non-glycosylated and glycosylated rhGM-CSF in rats after a single iv injection.

\begin{tabular}{|c|c|c|c|}
\hline & $\begin{array}{c}\boldsymbol{t}_{\mathbf{1 / 2}} \boldsymbol{\alpha} \\
(\mathbf{m i n})\end{array}$ & $\begin{array}{c}\boldsymbol{t}_{\mathbf{1} / \mathbf{2}} \boldsymbol{\beta} \\
(\mathbf{m i n})\end{array}$ & $\begin{array}{c}\mathrm{CL} \\
(\mathbf{m L} / \mathbf{m i n})\end{array}$ \\
\hline non-glycosylated rhGM-CSF & $2.1 \pm 0.2$ & $5 \pm 10$ & $2.83 \pm 0.09$ \\
\hline glycosylated rhGM-CSF & $4.9 \pm 0.6$ & $3 \pm 10$ & $1.07 \pm 0.05$ \\
\hline
\end{tabular}


Baenziger, 2004).

This also has been exploited to create new variants of existing products. For example, Aranesp (darbepoetin alfa) is an analogue of recombinant human erythropoietin that was approved in 2001. It has an increased sialic acid content, due to the introduction of two additional glycosylation sites in the EPO backbone, resulting in a significantly longer half-life than the native molecule (Egrie and Browne, 2001).

The thorough characterization of the glycosylation pattern of the mammalian derived cytokine used in this work showed that it has a high degree of branching where more than $90 \%$ of the galactose of the N-glycans capped with sialic acid residues. Microheterogeneity of the protein structure of rhGM-CSF by translational glycosylation processing results in differences in the degree of sialylation and different branching of the carbohydrate moieties, which give rise to about 16 isoforms with different $\mathrm{pI}$ values due to the presence of predominantly tri-and tetra-antennary $\mathrm{N}$ linked oligosaccharide chains (Forno et al. 2004).

Additionally, receptor-mediated removal appears to be the main pathway of metabolism for many proteins, thus, the increased half-lives of glycosylated proteins might be function of decreased receptor affinity and decreased receptor-mediated elimination from circulation (Koury, 2003).

Our findings show that glycosylation improved the pharmacokinetic parameters of rhGM-CSF. It is likely that the lower clearance of glycosylated rhGM-CSF will confer a clinical advantage over the non-glycosylated product by potentially allowing less frequent dosing in patients.

\section{REFERENCES}

ARMITAGE, James O. Emerging applications of recombinant human granulocyte-macrophage colonystimulating factor. Blood, December 1998, vol. 92, no. 12, p. 4491-4508.

BILGIN, Kemal; YARAMIS, Ahmet; HASPOLAT, Kenan; TAS, M. Ali; GUNBEY, Sacit and DERMAN, Orhan. A randomized trial of granulocyte-macrophage colonystimulating factor in neonates with sepsis and neutropenia. Pediatrics, January 2001, vol. 107, no. 1, p. 36-41.

BOLLATI FOGOLÍN, Mariela; OGGERO EBERHARDT, Marcos; KRATJE, Ricardo and ETCHEVERRIGARAY, Marina. Choice of the adequate quantification method for recombinant human GM-CSF produced in different host systems. Electronic Journal of Biotechnology [on line]. 15 December 2002, vol. 5, no. 3. Available from: http:/www.ejbiotechnology.info/content/vol5/issue3/full/6/ index.html. ISSN 0717-3458.

BOLLATI FOGOLÍN, Mariela; WAGNER, Roland; ETCHEVERRIGARAY, Marina and KRATJE, Ricardo.
Impact of temperature reduction and expression of yeast pyruvate carboxylase on hGM-CSF-producing CHO cells. Journal of Biotechnology, April 2004, vol. 109, no. 1-2, p. 179-191.

CEBON, Jonathan; NICOLA, Nicos; WARD, Marcia; GARDNER, Ian; DEMPSEY, Peter; LAYTON, Judith; DÜHRSEN, Ulrich; BURGESS, Antony; NICE, Edouard and MORSTYN, George. Granulocyte-macrophage colony stimulating factor from human lymphocytes. The effect of glycosylation on receptor binding and biological activity. The Journal of Biological Chemistry, March 1990, vol. 265, no. 8, p. 4483-4491.

CHITLARU, Theodor; KRONMAN, Chanoch; VELAN, Baruch and SHAFFERMAN, Avigdor. Overloading and removal of N-glycosylation targets on human acetylcholinesterase: effects on glycan composition and circulatory residence time. Biochemical Journal, May 2002, vol. 363, no. 3, p. 619-631.

DENZLINGER, C.; TETZLOFF, W.; GERHARTZ, H.H.; POKORNY, R.; SAGEBIEL, S.; HABERL, C. and WILMANNS, W. Differential activation of the endogenous leukotriene biosynthesis by two different preparations of granulocyte-macrophage colony-stimulating factor in healthy volunteers. Blood, April 1993, vol. 81, no. 8, p. 2007-2013.

DORR, Robert T. Clinical properties of yeast-derived versus Escherichia coli-derived granulocyte-macrophage colony-stimulating factor. Clinical Therapeutics, JanuaryFebruary 1993, vol. 15, no. 1, p. 19-29.

EGRIE, Joan C. and BROWNE, Jeffrey K. Development and characterization of novel erythropoiesis stimulating protein (NESP). Nephrology Dialysis Transplantation, June 2001, vol. 16, no. 3, p. 3-13.

FORNO, Guillermina; BOLLATI FOGOLÍN, Mariela; OGGERO, Marcos; KRATJE, Ricardo; ETCHEVERRIGARAY, Marina; CONRADT, Harald S. and NIMTZ, Manfred. N- and O-linked carbohydrates and glycosylation site occupancy in recombinant human granulocyte-macrophage colony-stimulating factor secreted by a Chinese hamster ovary cell line. European Journal of Biochemistry, March 2004, vol. 271, no. 5, p. 907-919.

FLEETWOOD, Andrew J.; COOK, Andrew D. and HAMILTON, John A. Functions of granulocytemacrophage colony-stimulating factor. Critical Reviews in Immunology, 2005, vol. 25, no. 5, p. 405-428.

GRIBBEN, J.G.; DEVEREUX, S.; THOMAS, N.S.B.; KEIM, M.; JONES, H.M.; GOLDSTONE, A.H. and LINCH, D.C. Development of antibodies to unprotected glycosylation sites on recombinant human GM-CSF. Lancet, February 1990, vol. 335, no. 8687, p. 434-437. 
HUSSEIN, Atif M.; ROSS, Maureen; VREDENBURGH, James; MEISENBERG, Barry; HARS, Vera; GILBERT, Colleen; PETROS, William P.; CONIGLIO, David; KURTZBERG, Joanne; RUBIN, Peter and PETERS, William P. Effects of granulocyte-macrophage colony stimulating factor produced in CHO cells (regramostim), Escherichia coli (molgramostim) and yeast (sargramostim) on priming peripheral blood progenitor cells for use with autologous bone marrow after high-dose chemotherapy. European Journal of Haematology, November 1995, vol. 54 , no. 5, p. 281-287.

KAUSHANSKY, Kenneth; O'HARA, Patrick J.; HART, Charles E.; FORSTROM, John W. and HAGEN, Frederick S. Role of carbohydrate in the function of human granulocyte-macrophage colony-stimulating factor. Biochemistry, July 1987, vol. 26, no. 15, p. 4861-4867.

KOURY, Mark J. Sugar coating extends half-lives and improves effectiveness of cytokine hormones. Trends in Biotechnology, November 2003, vol. 21, no. 11, p. 462464.

MITRA, Nivedita; SINHA, Sharmistha; RAMYA, Thirumalai N.C. and SUROLIA, Avadhesha. N-linked oligosaccharides as outfitters for glycoprotein folding, form and function. Trends in Biochemical Sciences, March 2006, vol. 31, no. 3, p. 156-163.

PARK, Eric I. and BAENZIGER, Jacques U. Closely related mammals have distinct asialoglycoprotein receptor carbohydrate specificities. The Journal of Biological Chemistry, September 2004, vol. 279, no. 39, p. 4095440959.

REVOLTELLA, Roberto P.; LARICCHIA-ROBBIO, Leopoldo; MOSCATO, Stefania; GENUA, Angelo and LIBERATI, Anna M. Natural and therapy-induced antiGM-CSF and anti-G-CSF antibodies in human serum. Leukemia and Lymphoma, December 1997, vol. 26, no. 1, p. 29-34.

RUDD, Pauline M.; ELLIOTT, Tim; CRESSWELL, Peter; WILSON, Ian A. and DWEK, Raymond A. Glycosylation and the immune system. Science, March 2001, vol. 291, no. 5512, p. 2370-2376.

SHARGEL, Leon; WU-PONG, Susanna and YU, Andrew B.C. Applied biopharmaceutics and pharmacokinetics. $5^{\text {th }}$ ed. New Baskerville, McGraw-Hill, 2005. 892 p. ISBN 007-137550-3.

STUTE, Norbert; FURMAN, Wayne L.; SCHELL, Michael and EVANS, William E. Pharmacokinetics of recombinant human granulocyte-macrophage colony-stimulating factor in children after intravenous and subcutaneous administration. Journal of Pharmaceutical Sciences, July 1995 , vol. 84 , no. 7 , p. 824-828.
TRINDADE, Eunice; MATON, Pierre; REDING, Raymond; DE VILLE DE GOYET, Jean; OTTE, Jean Bernard; BUTS, Jean Paul and SOKAL, Etienne M. Use of granulocyte macrophage colony stimulating factor in children after orthotopic liver transplantation. Journal of Hepatology, June 1998, vol. 28, no. 6, p. 1054-1057.

WADHWA, Meenu; BIRD, Chris; FAGERBERG, Jan; GAINES-DAS, Rose; RAGNHAMMAR, Peter; MELLSTEDT, Hakan and THORPE, Robin. Production of neutralizing granulocyte-macrophage colony-stimulating factor (GM-CSF) antibodies in carcinoma patients following GM-CSF combination therapy. Clinical and Experimental Immunology, May 1996, vol. 104, no. 2, p. 351-358.

WADHWA, Meenu; HJELM SKOG, Anna-Lena; BIRD, Chris; RAGNHAMMAR, Peter; LILLJEFORS, Maria; GAINES-DAS, Rose; MELLSTEDT, Hakan and THORPE, Robin. Immunogenicity of granulocyte-macrophage colony-stimulating factor (GM-CSF) products in patients undergoing combination therapy with GM-CSF. Clinical Cancer Research, June 1999, vol. 5, no. 6, p. 1353-1361.

WALSH, Gary. Biopharmaceutical benchmarks - 2003. Nature Biotechnology, August 2003, vol. 21, no. 8, p. 865870. 